九州大学学術情報リポジトリ

Kyushu University Institutional Repository

\title{
STUDIES ON THE SUBFAMILY STENINAE (COLEOPTERA, STAPHYLINIDAE) FROM JAPAN, XVI. DESCRIPTIONS OF FOUR NEW SPECIES OF THE SUBGENUS HYPOSTENUS OF THE GENUS STENUS LATREILLE
}

Naomi, Shun-ichiro

Nomura, Shuhe i

https://doi.org/10.5109/2525

出版情報 : ESAKIA. Special Issue 1, pp.45-49, 1990-04-20. Entomological Laboratory, Faculty of Agriculture, Kyushu University

バージョン:

権利関係 : 


\title{
STUDIES ON THE SUBFAMILY STENINAE (COLEOPTERA, STAPHYLINIDAE) FROM JAPAN, XVI. DESCRIPTIONS OF FOUR NEW SPECIES OF THE SUBGENUS HYPOSTENUS OF THE GENUS STENUS LATREILLE*
}

\author{
ShU N-ICHIRO N A OMI \\ Natural History Museum and Institute, Chiba \\ 955-2, Aoba-cho, Chiba, 280 Japan \\ and \\ ShuHeI N OMURA \\ Entomological Laboratory, Faculty of Agriculture, \\ Kyushu University, Fukuoka, 812 Japan
}

\begin{abstract}
Four new species of the subgenus Hypostenus of the genus Stenus Latreille, Stenus amma, S. uenoi,S.masatakai, and S. warabi are described and their male genitalia are figured for comparison.
\end{abstract}

\section{Stenus amma sp. nov.}

Male. Body length : $3.1 \mathrm{~mm}$.

Body including mouth parts yellow and moderately shiny ; antennae yellowish brown except for 4 yellowish basal segments; legs pale yellow.

Head broader than elytra (1.21:1), 1.70 times as broad as long, frontoclypeal area sparsely haired, interocular area almost flat, with a pair of depressions, the depressions very shallow and indistinct ; punctures moderate in density and size, round and almost regular, interstices between punctures indistinctly sculptured and shiny. Antennae reaching a little before hind margin of pronotum, 7th to 10th segments gradually broadened apically, with relative lengths of segments from base to apex as $9: 9: 15: 10: 9: 7: 6: 5: 5: 7: 9$.

Pronotum about as long as elytra, as long as broad, evenly convex, broadest at anterior $2 / 5$; disk almost even, with an indefinite median depression ; punctures large, dense and almost regular, interstices between punctures narrow, moderately shiny and clearly sculptured.

Elytra broader than long (1.11: 1), gently convex above, side margins much rounded, hind

* Contribution from the Entomological Laboratory, Faculty of Agriculture, Kyushu University, Fukuoka (Ser. 4, No. 5). 
margins together forming a very shallow and wide emargination, sutural area slightly raised ; punctures round to elongate oval, dense, large and deeper than those on head, interstices between punctures indistinctly sculptured and very narrow.

Legs moderately long, femora thick, hind tarsi 0.66 times as long as hind tibiae.

Abdomen gradually narrowed posteriorly ; punctures becoming gradually smaller posteriorly from 3rd to 8th segments ; pubescence fine and regular ; 6th and 7th sterna each with a flat median area in full length ; 8th sternum with a moderate V-shaped emargination at the middle of posterior margin ; 9th sternum with a pair of posterolateral projections pointed and bent downward, posterior margin between the projections weakly serrate and truncate. Genitalia (Fig. 1 A) with median lobe elongate oval, broadest at basal $2 / 5$, then gradually narrowed apically, with dull apicolateral angles, peripheral area moderately sclerotized in apical half and a small notch at the middle of apical margin ; parameres extending beyond apex of median lobe, each swollen at apical part, with several hairs at apicointernal part.

F emale. Unknown.

HoLotyPe : male, Ikeda City, Osaka-fu, 25. v. 1985, S. Nomura leg.

Distribution. Japan (Honshu).

Remarks. This new species belongs to the 3rd group of S. rufescens complex judging from the structure of male genitalia and is allied to S. taoi Naomi, but is separable from the latter by the following characters. The body is entirely yellow, the median lobe is almost gradually narrowed from basal 2/5 to apex and the parameres are swollen at the apical parts in the male genitalia.

\section{Stenus uenoi sp. nov.}

M ale and female. Body length : $3.2-3.9 \mathrm{~mm}$.

Body dark brown to black and moderately shiny; labrum, mandible and antennae reddish brown; maxillary palpi light reddish brown; legs yellowish brown to reddish brown.
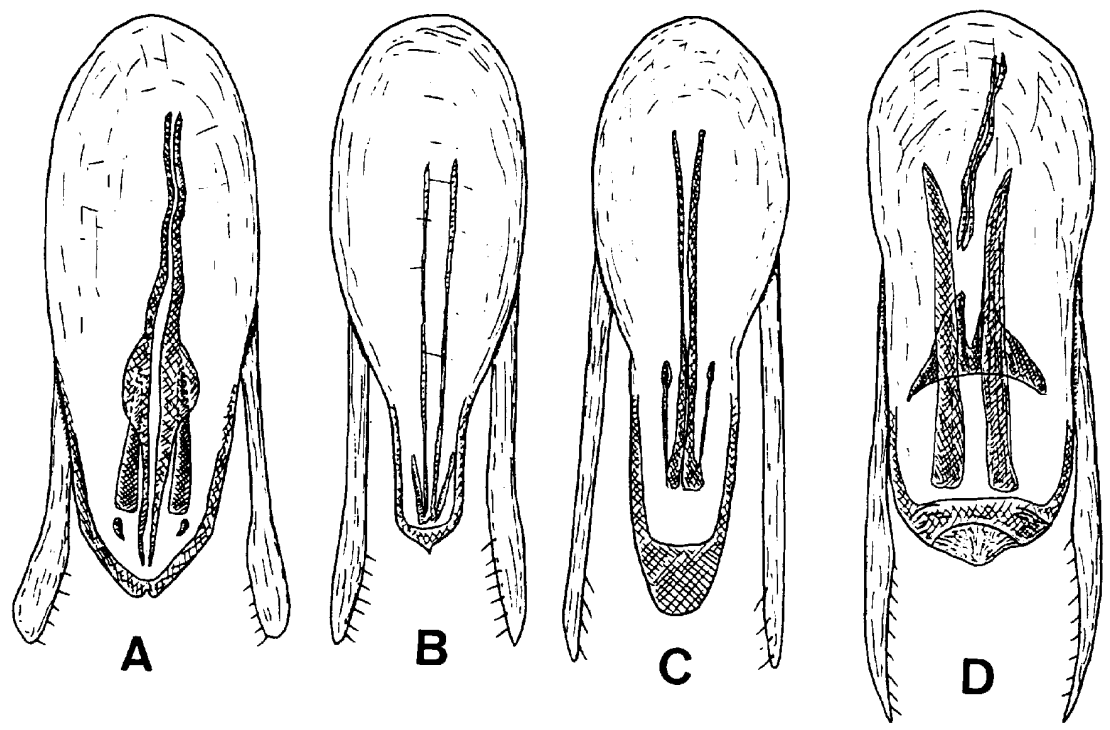

Fig. 1. A-D, Male genitalia in dorsal view. A, Stenus amma sp. nov. ; B, S. uenoi sp. nov. ; C, S. masatakai sp. nov. ; D, S. warabi sp. nov. 
Head broader than elytra (1.1: 1), 1.56 times as broad as long, frontoclypeal area sparsely pubescent, interocular area with a pair of depressions, the depressions longitudinal, narrowed and becoming deeper anteriorly, median part between the depressions gently convex, with posterointemal parts of antennal insertions distinstly keeled and shiny ; punctures small, round, regular and a little sparser than those on 3rd abdominal tergum ; interstices between punctures distinctly sculptured. Antennae reaching posterior $4 / 5$ of pronotum, 8th segment smallest, 9th to 10 th each elliptical, with relative lengths of segments from base to apex as $10: 9: 18: 10: 9: 6: 6: 4: 6: 6: 10$.

Pronotum a little shorter than elytra $(0.95: 1)$, about as long as broad, moderately convex above, broadest at anterior $1 / 3$, constricted in basal $1 / 3$; disk almost even, with a median longitudinal depression, the depression about $2 / 3$ times as long as pronotum; punctures very dense, subrugose and rough, interstices between punctures indistinctly sculptured.

Elytra broader than long $(1.13: 1)$, weakly constricted at base, hind margins together forming a wide and shallow emargination; punctures very large, rough and dense, distortionally round to elliptical in shape, interstices between punctures indistinctly sculptured.

Legs moderate in length and thickness, hind tarsi 0.63 times as long as hind tibiae.

Abdomen a little narrowed posteriorly or subparallel-sided ; punctures on 3rd tergum dense and their diameters larger than interstices between punctures, but punctures on 8th tergum are very fine ; pubescence dense, regular and fine.

M ale. Seventh sternum with a very shallow median depression at posterior part ; 8th sternum with a median $\mathrm{V}$-shaped emargination ; 9th sternum with a pair of apicolateral projections which are acutely pointed, posterior margin between the projections moderately emarginate and weakly serrate. Genitalia (Fig. 1 B) with median lobe bulbous in basal 2/3, parallel-sided and narrow in apical 1/3, with pointed apex, internal armatures very thin ; parameres extending beyond apex of median lobe, robust and feebly curved outward, each with several hairs on apicointemal part.

Female. Eighth sternum obtusely pointed at the middle of posterior margin.

Holotype : male, Odona, Neba-mura, Nagano Pref., 28. x. 1985, S. Nomura leg. Paratypes : 15 exs., same data as holotype ; 2 exs., Mt. Togakushi, Nagano Pref., 26. viii. 1983, S. Nomura leg ; 1 ex., Mt. Sanage, Aichi Pref., 24. x. 1970, K. Yamagishi leg.; 11 exs., Goushima, Haruno-cho, Shizuoka Pref., 23. x. 1985, S. Nomura leg.

Distribution. Japan (Honshu).

REMARKS. This new species belongs to the 6th group of S.rufescens complex and is separable from the members of this group by the following characters. The 7 th sternum is weakly depressed at the middle of posterior part and the median lobe is parallel-sided in the apical $1 / 3$ of the male genitalia.

This new species is named in honor of Dr. Shun-Ichi Uéno of the National Science Museum, Tokyo for his kind encouragement to our study on the subfamily Steninae of Japan.

\section{Stews masatakai sp. nov.}

M ale and female. Body length : 3.1-3.3 mm.

Head and abdomen black and moderately shiny ; pronotum and elytra light brown to dark brown and shiny ; labrum, mouth parts and antennae reddish brown to brown; legs yellow to reddish yellow.

Head broader than elytra (1.20:1), 1.67 times as broad as long, frontoclypeal area with sparse hairs of different lengths, interocular area weakly concave, with a pair of depressions, the depressions longitudinal and broad, median part between the depressions moderately convex ; punctures round and moderate in density and size, interstices between punctures distinctly sculptured. Antennae 
reaching a little before hind margin of pronotum, 8 th to 11 th segments forming a loose club, with relative lengths of segments from base to apex as $10: 8: 18: 9: 7: 7: 5: 4: 5: 6: 8$.

Pronotum a little longer than elytra $(1.08: 1)$ and broader than long $(1.08: 1)$, broadest at about the middle to anterior $2 / 5$; disk almost even, with a median longitudinal depression, the depression about $2 / 3$ times as long as pronotum ; punctures round, dense and almost regular, interstices between punctures distinctly sculptured.

Elytra broader than long (1.21: 1), weakly uneven, constricted at base, side margins gently rounded, hind margins together forming a broad, shallow and arcuate emargination ; punctures very dense, large, round and a little larger than those on pronotum, interstices between punctures very narrow and sculptured.

Legs elongate, hind tarsi 0.63 times as long as hind tibiae.

Abdomen a little narrowed posteriorly ; punctures and pubescence similar to those in S. uenoi sp. nov.

M ale. Sixth and 7th sterna each smoothly convex ventrally ; 8th sternum with a shallow Vshaped emargination at posterior margin ; 9th sternum with a pair of acutely pointed apicolateral projections, hind margin between the projections weakly serrate and arcuately emarginate. Genitalia (Fig. 1C) with median lobe bulbous in basal half, narrow and subparallel-sided in apical half, subtruncate at apex, and moderately sclerotized in apical 1/10, with internal armatures thin; parameres straight, extending beyond apex of median lobe, each with a few setae at apicointernal part.

Female. Abdomen a little broader than in male ; 8th sternum obtusely pointed at the middle of apical margin.

Holotype : male, Urahikimi, Shimane Pref., 24. viii. 1988, K. Ogata leg. Paratypes ; 13 exs., same locality, 6-7. vi. 1988, S. Nomura leg. ; 4 exs., Nakatsuya Valley, Yoshiwa-mura, Hiroshima Pref., 7-8. vi. 1987, S. Nomura leg.

Distribution. Japan (Honshu).

REMARKS. Stenus masatakai sp. nov. belongs to the 6th group of S. rufescens complex, and is allied to S. uenoi sp. nov. The former species is, however, separable from the latter by the straight parameres and the subtruncate apex of the median lobe in the male genitalia.

This new species is named in honor of Prof. Masataka Sato of the Nagoya Women's University for his kindness in giving us valuable stenine specimens.

\section{Stenus warabi sp. nov.}

M ale and female. Body length : 3.2-3.3 mm.

Body dark brown to black and moderately shiny ; labrum dark reddish brown ; antennae and maxillary palpi yellowish brown to reddish brown; legs reddish brown.

Head broader than elytra $(1.24: 1), 1.63$ times as broad as long, frontoclypeal area sparsely haired, interocular area with a pair of broad and longitudinal depressions, median part between the depressions weakly convex ; punctures moderate in density and size, and round, interstices between punctures distinctly sculptured. Antennae reaching a little before hind margin of pronotum, 8th segment smallest, 9th to 11th forming a loose club, with relative lengths of segments from base to apex as $10: 10: 16: 10: 9: 6: 6: 4: 5: 6: 9$.

Pronotum a little longer than elytra $(1.09: 1)$, about as long as broad, broadest at about middle to anterior $2 / 5$, side margins rounded; disk weakly uneven, with an indistinct depression, the depression about half length of pronotum ; punctures dense, round and subrugose, interstices between punctures distinctly sculptured. 
Elytra broader than long (1.20:1), slightly uneven, rounded at sides, hind margins together forming a wide, shallow and V-shaped emargination ; punctures dense, round and rough, interstices between punctures narrow and indistinctly sculptured.

Legs moderately in length, femora thick, hind tarsi 0.70 times as long as hind tibiae.

Abdomen weakly narrowed posteriorly ; punctures round and regular, and interstices between punctures narrower than diameters of punctures and indistinctly sculptured on 3rd tergum, punctures becoming gradually smaller posteriorly from 3rd to 8th segments ; pubescence reddish, decumbent and sparse.

Male. Sixth and 7th sterna each smoothly convex ventrally; 8th sternum with a moderate emargination at the middle of posterior margin ; 9th sternum with a pair of pointed apicolateral projections, hind margin between the projections subtruncate. Genitalia (Fig, 1 D) with median lobe robust and broad, bulbous at basal half, widely and arcuately emarginate at apical margin, but apical part has a thin and subtransparent board at its ventral side, so that it looks like "entire condition" when seen from dorsal side, internal armatures with two pairs of bands and a median W-shaped structure, the anterior bands thin and twisted, shorter and narrower than the posterior.

Female. Eighth sternum obtusely pointed at the middle of posterior margin.

Holotype : female, Hyonosen, Hyogo Pref., 5. vi. 1984, S. Nomura leg. Paratype : 1 male, same data as holotype.

Distribution. Japan (Honshu).

REmarks. The systematic position of this new species is problematic because the shape of the male genitalia shows an intermediate condition between the 7th and 9th groups of S.rufescens complex. Namely, the parameres and general shape of male genitalia resemble those in the 9th group, but this species resembles the 7th group in the presence of a large emargination at the apical margin of median lobe. In this study, we tentatively include this species in the 9th group. Stenus warabi sp. nov. is easily separable from all the members in the 7th and 9th groups by the presence of a thin and subtransparent board at the apicoventral side of median lobe.

\section{Acknowledgement}

We wish to express our hearty thanks to Prof. Emer. Yoshihiro Hirashima for his kind guidance, and we would like to dedicate this paper to him in commemoration of his retirement from Kyushu University, Fukuoka.

\section{$R$ eferences}

Naomi, S., 1989. Studies on the subfamily Steninae (Coleoptera, Oxyporidae) from Japan, X. Subgenus Hypostenus of the genus Stenus Latreille (Part 2). Akitu.N. S. (105) : 1-11.

Naomi, S., 1989. Studies on the subfamily Steninae (Coleoptera, Oxyporidae) from Japan, XIII. Subgenus Hypostenus of the genus Stems Latreille, Part 5. Elytra, Tokyo, 17(2): 159-167.

Naomi, S., (In press). Studies on the subfamily Steninae (Coleoptera, Oxyporidae) from Japan, XIV. Subgenus Hypostenus of the genus Stems Latreille, Part 6. Jpn.J. Ent. 